\title{
Historic Atlases of Polish Towns - status at the end of 2018
}

\author{
Zenon Kozieł $^{\mathrm{a}, *}$, Radosław Golba ${ }^{\mathrm{a}}$, Agnieszka Pilarska ${ }^{\mathrm{a}}$ and Roman Czaja ${ }^{\mathrm{b}}$ \\ ${ }^{a}$ Faculty of Earth Sciences, Department of Geomatics and Cartography, Nicolaus Copernicus University, Lwowska Str. 1, 87-100 \\ Toruń, Poland, korzen@umk.pl \\ ${ }^{b}$ Faculty of History, Department of Medieval History, Nicolaus Copernicus University, W. Bojarskiego Str. 1, 87-100 Toruń, \\ Poland,rc@umk.pl
}

Keywords: history of towns in cartography, editorial assumptions for the atlas, traditional version and online atlas

\begin{abstract}
:
The Historic Atlas of Polish Towns, which makes up a part of an international project covering the towns of Europe, has been implemented in Poland since the early 1990s. This project was presented recently at the poster session during the $26^{\text {th }}$ International Cartographic Conference in Germany (Dresden 2013). In consequence of subsequent files of the Atlas for twenty Polish towns being published in the past five years, their presenting within the panel session, during 29 ICC (Tokyo'2019) seems of importance. Polish towns for which the atlases were developed are: Bochnia, Chojnice, Fordon, Gliwice, Jelenia Góra, Kętrzyn, Koronowo, Milicz, Mrągowo, Namysłów, Oława, Ostróda, Sandomierz, Strzegom, Strzelin, Wieliczka, Włocławek, Wrocław, Ząbkowice Śląskie and Ziębice. Familiarizing the public with this cycle of historic atlases consitutes also a good opportunity to recall the origins of the project as its history dates back to the mid-1960s, and thus is similar to the history of the cycles of International Cartographic Conferences.
\end{abstract}

The basic principles for editing historic atlases of towns were worked out at the 1968 Oxford conference of historians and cartographers, and then, discussed again and supplemented with the principles for unified edition, at the 1995 Münster (Germany) „Atlas Publishers” conference. In 1965, the International Commission for the History of Towns gave an impulse to the historic atlases of towns, during the Vienna Congress, when it decided to place in its programme, the patronage over the edition of towns' atlases. Given the recommendations of this Commission, historic atlases of European towns shall be published in the form of separate files for each town and so that the necessary minimum includes the following four principal maps for each town:

a) the $19^{\text {th }}$ century cadastral plan, that is from a pre-industrial period, at a scale of $1: 2,500$;

b) the $19^{\text {th }}$ century map, contemporary with the cadastral plan, generally at a scale of 1:25,000;

c) a spatial development plan for the town from the Mediaeval to contemporary times, at a scale of 1: 5,000;

d) a modern town plan.

Regardless of this, atlases may contain (according to the capabilities of publishers) thematic maps and reproductions of the most interesting cartographic sources and panoramas. However, this assumption can be implemented only in the case the suitable cartographic sources have been preserved. For example, one of the most voluminous atlases among those listed above is the Atlas of Wrocław dated from 2017, counting 110 maps and plans.

An integral part of each atlas, as a scientific study, is a concise historic commentary, describing the history of the town, with particular emphasis put on its spatial layout development. Notwithstanding the main scientific objective, individual files of the Atlas can also be useful for other needs, and in particular for:

a) urban, architectural and conservation works, environmental protection;

b) schools and universities' teaching and didactic objectives;

c) popularizing towns' past.

In accordance with the idea of the International Commission for the History of Towns, the main task of this edition of atlases shall be founding a single source database for research on the urbanization of Europe and spatial changes of towns. Therefore, it must also have its language adapted so as to fulfill this function. It is necessary to use in comments and explanations, not only the national language, but also one of the congress languages (English, French, Spanish, German, Russian, or Italian). For the edition of Polish atlases, the German language was chosen primarily, due to the particular interest of our western neighbours, in the history of Polish towns. There happen, however, explanations in both; German and English. Initially, the project of the historic atlas of Polish towns was carried out only in Torun by a team under the guidance of Roman Czaja (historical editing) and Zenon Kozieł (cartographic editing). In the subsequent years, work on the historic atlas of the Śląsk/Silesian towns was taken over by the Wrocław team under the guidance of Marta Młynarska-Kaletynowa (currently of Rafał Eysymontt) whereas the Kraków team, published atlases of the Małopolska/Little Poland towns under the guidance of Zdzisław Noga.

Up to now, under the patronage of the International Commission for the History of Towns, atlases for over 530 towns from eighteen European states have been published (https://www.ria.ie/research-projects/irish-historic-towns-atlas/ european-project), of which 34 (i.e. 6,5\%) are those made for Polish towns. 